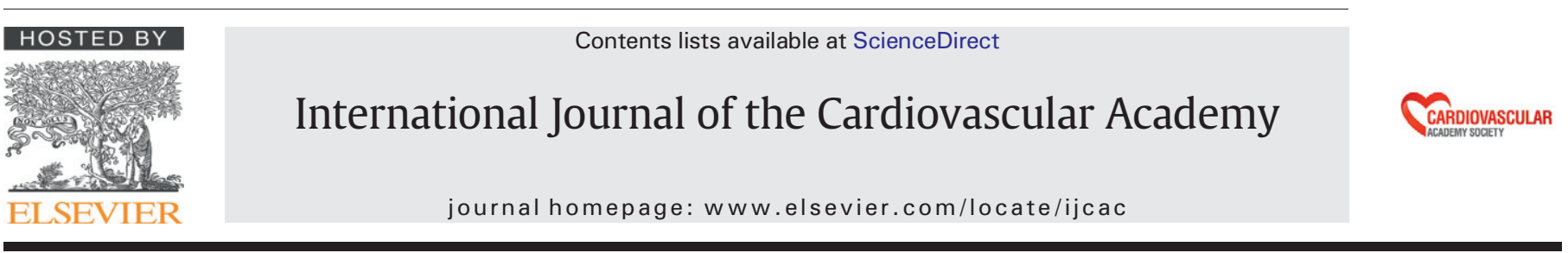

Short communication

\title{
A huge left ventricular pseudoaneurysm manifesting as acute dyspnea
}

\author{
Aksüyek Savaş Çelebi ${ }^{\mathrm{a}}$, Özlem Özcan Çelebi ${ }^{\mathrm{b}, *}$, Erdem Diker ${ }^{\mathrm{b}}$ \\ a Department of Cardiology, TOBB ETU Hospital, Ankara, Turkey \\ b Department of Cardiology, Medicana International Hospital, Ankara, Turkey
}

\section{A R T I C L E I N F O}

\section{Article history:}

Received 30 April 2015

Received in revised form 3 July 2015

Accepted 5 July 2015

Available online 17 August 2015

\section{Keywords:}

Pseudoaneurysm

Transthorasic echocardiography

\begin{abstract}
A B S T R A C T
Pseudoaneurysm of the left ventricle (LV) is one of the mechanic complications of myocardial infarction. This rare complication mostly stems from inferior wall of the LV. The wall of pseudoaneurysm contains pericardium and/or scar tissue but not myocardium. Transthorasic echocardiography is commonly used in clinical practice and is usually sufficient to make a diagnosis of LV pseudoaneurysm. It is important to differentiate pseudoaneurysm from true LV aneurysm. Pseudoaneursym does not contain myocardial tissue whereas true LV aneurysm does. Pseudoaneurysm also has narrow neck unlike true LV aneurysm. Urgent surgical approach is indicated because of fatal rupture. Here we report a case report of pseudoaneurysm manisfesting with acute dyspnea.

(C) 2015 The Society of Cardiovascular Academy. Production and hosting by Elsevier B.V. All rights reserved. This is an open access article under the CC BY-NC-ND license (http://creativecommons.org/licenses/by-nc-nd/4.0/).
\end{abstract}

\section{Case report}

65-year-old man was admitted to our department with acute and acute dyspnea within 2 h (New York Heart Association functional class III). He had a past medical history of coronary artery disease and heart failure. His previous transthoracic echocardiography (TTE), which was performed 1 month ago, showed hypokinesia of both inferior and anterior segments with ejection fraction (EF) of $\% 30$. He was on aspirin, statin and beta-blocker therapy. Cardiovascular examination was notable for bilateral pulmonary rales and S3, which were consistent with heart failure. Electrocardiography revealed q waves in inferior and anterior leads. TTE showed severe depression of LV systolic function $(E F=\% 15)$ and a giant extra chamber next to inferior wall of LV. This extra chamber was surrounded by parietal pericardium and was consistent with pseudoaneurysm (Fig. 1). Parenteral diuretic and nitroglycerine were started and he was urgently referred for surgery.

Pseudoaneurysm of the left ventricle (LV) is one of the mechanic complications of myocardial infarction and mostly stems from inferior wall ${ }^{1}$. It is caused by contained rupture of LV free wall ${ }^{2}$. The wall of pseudoaneurysm contains pericardium and/or scar tissue but not myocardium ${ }^{3}$. The diagnosis might be difficult to make since a pseudoaneurysm is easily confused with a true aneurysm. In contrast to true aneurysm, pseudoaneurysm has narrow neck. TTE is commonly used in clinical practice and is usually sufficient to make a diagnosis of

\footnotetext{
* Corresponding author at: Medicana International Ankara Hastanesi, Kardiyoloji Kliniği, 06510 Ankara, Turkey. Tel.: +90 31229292 92; fax: +90 3122203170. E-mail address: drozlemoz79@yahoo.com (Ö.Ö. Çelebi).

Peer review under responsibility of The Society of Cardiovascular Academy.
}

LV pseudoaneurysm like this currently presented case. There is an indication for urgent surgical resection of pseudoaneurysm due to the risk of fatal rupture ${ }^{3,4}$.

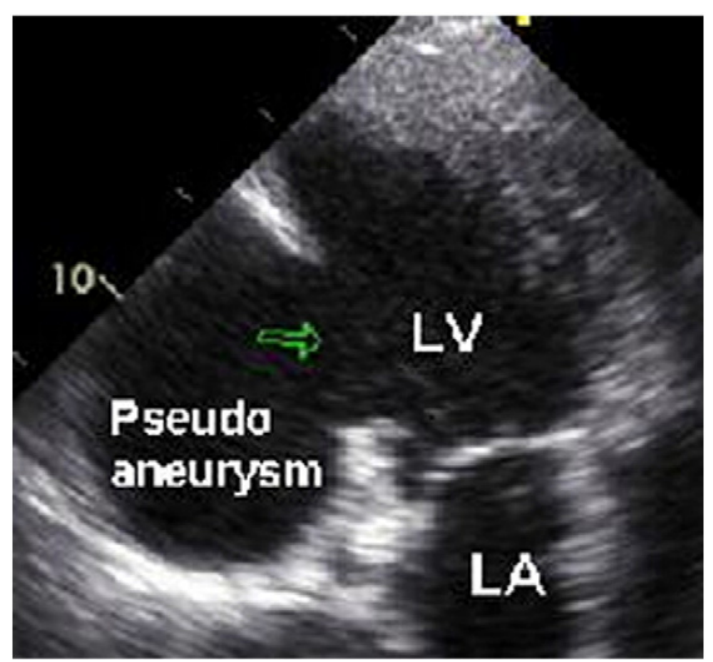

Fig. 1. Transthorasic echocardiography shows inferior left ventricular pseudoaneurysm through a narrow neck (arrow) in apical 2-chamber view. $L V=$ left ventricle, $L A=$ left atrium. 


\section{References}

1. Komeda M, David TE. Surgical treatment of postinfarction false aneurysm of the left ventricle. J Thorac Cardiovasc Surg 1993;106(6):1189-1191.

2. Mahilmaran A, Nayar PG, Sheshadri M, Sudarsana G, Abraham KA. Left ventricular pseudoaneurysm caused by coronary spasm, myocardial infarction, and myocardial rupture. Tex Heart Inst J 2002;29(2):122-125.
3. Vlodaver Z, Coe JI, Edwards JE. True and false left ventricular aneurysms. Propensity for the latter to rupture. Circulation 1975;51(3):567-572.

4. Yilik L, Yetkin U, Tulukoğlu E, Gürbüz A. Surgical approach of a giant left ventricular pseudoaneurysm. T Klin Kalp Damar Cerrahisi 2004;5(2):39-43. 